\title{
Globalization, Sovereignty and Social Unrest
}

\author{
Jennifer Westaway ${ }^{1}$ \\ ${ }^{1}$ School of Business Law and Taxation, Curtin University, Australia \\ Correspondence: Jennifer Westaway, School of Business Law and Taxation, Curtin University, GPO Box U1987, \\ Perth 6957, Western Australia. Tel: 61-8-9266-3945. E-mail: jennifer.westaway@cbs.curtin.edu.au
}

Received: February 8, 2012

Accepted: February 23, 2012

Online Published: June 1, 2012

doi:10.5539/jpl.v5n2p132

URL: http://dx.doi.org/10.5539/jpl.v5n2p132

\begin{abstract}
The world has seen over recent months an increase in the level of social unrest in response to both the imposition by governments of austerity measures and attempts by civilians to overthrow undemocratic and repressive regimes. This unprecedented and extensive level of unrest across diverse political and economic environments has raised many questions as to the causes and consequences, not the least of which is the challenge to the sovereignty of the state and the role of globalization. This paper will discuss the social unrest consequences of globalization and consider whether globalization has undermined the concept of state sovereignty to such an extent that the social unrest in evidence is in effect the beginning of a new era in international law and international relations.
\end{abstract}

Keywords: globalization, sovereignty, social unrest, international law

\section{Introduction}

Over recent months, the world has seen an unprecedented level of political and social unrest sweeping through the Arab world and Greece, as well as Italy, Spain, and the United Kingdom. Whilst it may be convenient to see this unrest as a long term consequence of the global financial crisis and its aftermath, it is arguable that this unrest has its foundation in the failure of countries to understand and address the social consequences of globalization.

There are many descriptions and definitions of globalization and the term is used in many different contexts. Joseph Stiglitz (2002:9) describes globalization as “...the closer integration of the countries and peoples of the world which has been brought about by the enormous reduction of costs of transportation and communication, and the breaking down of artificial barriers to the flows of goods, services, capital, knowledge, and (to a lesser extent)) people across borders.”. According to Sjolander (1996:604) globalization is “...an economic, political, social, and ideological phenomenon which carries with it unanticipated, often contradictory, and polarizing consequences.” The International Monetary Fund (1997) has defined globalization as “...the rapid integration of economies worldwide through trade, financial flows, technology spillovers, information networks, and cross-cultural currents." Gunter \& van der Hoeven (2004) used the term to mean "the gradual integration of economies and societies driven by new technologies, new economic relationships and the national andinternational policies of a wide range of actors, including governments, international organizations, business, labour and civil society.” Finally, for the purposes of this paper, Seita (1997: 431) encapsulates the varying definitions when he states that globalization "...is a multifaceted concept encompassing a wide range of seemingly disparate processes, activities and conditions...connected together by one common theme: what is geographically meaningful now transcends national boundaries and is expanding to cover the entire planet. Globalization has led to an awareness that international issues, not just domestic ones, matter..."while Yates (1999) discusses globalization in a dual context of economics and politics, where economic globalization encompasses changes in production, markets, trade and capital flows, while political globalization refers to a changing global framework around awareness, processes and political activity.

Whatever the definition or description adopted, there is a clear theme throughout: that globalization has a clear and significant social dimension which encompasses security, cultural identity, social welfare, individual identity, and social cohesiveness. A failure to address these social dimensions impacts directly on wages, poverty, social welfare programs, migration, and cultural integration, and the political consequences for governments are no longer prospective but real. 
This paper will discuss the social unrest consequences of globalization and consider whether globalization has undermined the concept of statesovereignty to such an extent that the social unrest in evidence is in effect the beginning of a new era in international law and international relations. (Note 1).

\section{Sovereignty and Globalization}

Writing on the ethics of globalization, Singer (2002) argues that implicit in the term 'globalization' is an understanding that we are moving beyond cooperation between sovereign states, something he calls 'internationalization' to a new understanding or conception of what is a nation-state. In the words of the United Nations High Level Panel on Financing for Development (2001)

"In the global village, someone else's poverty very soon becomes one's own problem: of lack of markets for one's products, illegal immigration, pollution, contagious disease, insecurity, fanaticism, terrorism...”

Sovereignty as a concept under international law, as with the term globalization, has been various described (Westaway \& Simpson, 2011) but the judgment of Arbitrator Huber in the Island of Palmas(Miangas) Case (1932) is oft quoted:

"Sovereignty in the relations between States signifies independence. Independence in regard to a portion of the globe is the right to exercise therein, to the exclusion of any other State, the functions of a State. The development of the national organisation of States during the last few centuries and, as a corollary,the development of international law, have established this principle of the exclusive competence of the State in regard to its own territory in such a way as to make it the point of departure in settling most questions that concern international relationships."

A critical aspect of sovereignty is that it forms a basic structure of governance which forges a social bond between citizens and, citizens and the state. This basic structure of governance is expected toprovide the meet the objectives of peace, order, justice, and security within the state, with the sovereign statemanaging itsnational economy to achieve these objectives. As discussed by Devetak\&Higgott (1999) sovereign states have the obligation to govern the economy in such a way as to promote the wealth and welfare of the community, ensuring liberty, security and prosperity of the community and ensuring that the specific social needs of the community are met.

Territorial sovereignty, that which defines the physical parameters within which the exclusive right to display the activities of a State are contained, is a still a legal relevancy as it sets identifiable parameters around which decisions can be made. Indeed, Devetak\&Higgott (1999:487) note that the existence and boundaries of justice within a society have been traditionally thought be to be "coextensive with the legal-territorial jurisdiction and economic reach of the sovereign polity." Globalization and its impacts have however challenged the exclusive competence of the State to exercise autonomous powers under the umbrella of territorial sovereignty, where the exercise of that exclusive competence directly impacts upon the globalized framework of that State. Further, it is arguable that sovereignty is no longer either practical or adequate as a tool for organizing political life and meeting the social needs of the state, given that states no longer exist in a purely autonomous economic environment, but rather exist in an inter-dependent international community, where it is no longer possible for states merely to choose what international laws they accept or decide with autonomy what they will or will not regulate (Kwakwa, 2000).

Howard-Hassmann (2004) takes this argument further when he argues that while globalization has effectively diminished the relevance of the individual state, and that what has evolved is a concept of world citizenship, which encourages the individual to look beyond territorial sovereign borders and to claim rights, freedoms, choices and opportunities otherwise unknown to them but perceived to be part of the global world in which they live. The consequence can be a growing resentment of the constraints and policies of the State leading to social activism, social unrest and political instability and it is these consequences that this paper will now address.

\section{Globalization and Social Unrest}

One of the key facilitators of globalization has been liberalization in political, financial and trade markets. Where liberalization occurs, arguably there are qualitative changes in political and economic structures, trends and processes (Yates, 1999), as governments seek to adjust to and benefit from this liberalization and the changes in capital flow which accompany it. Hurtado(1997) suggested that political and social institutions were inadequately prepared to deal with the complex international social relations accompanying globalization and that this in turn gave rise to what he called the "ungovernability phenomena". This phenomenon was driven by poverty and other forms of social marginalisation within societies which threatened the rule of law and the authority of the state. This undermining of authority in turn increases violence, corruption and increasing 
political dissatisfaction and unrest (UN, 2011).

In writing on the relationship between the World Trade Organisation and the global economy, Blackhurst (1997:531) stated:

"To a large extent, governments have only themselves to blame for the backlash. Part of the problem is their frequent lack of candour regarding the fact that even though globalization clearly benefits the country as a whole, some groups in the economy will lose...More important is their reluctance to publicly acknowledge that while globalization creates tremendous opportunities, it also raises the cost of bad policies - such as labour market rigidities, over-regulation, sub-standard schools and educational policies, tax policies that discourage job creation, and chronic budget deficits that reduce investment by reducing national savings."

Built into this backlash against 'bad policies' as stated above is the sense that social capital is being undermined. According to Stiglitz (2003), because a country's identity is defined by its culture, and because globalization often brings with it a clash between traditional cultures and new cultures, with the result being that the traditional cultures lose out, and there is a backlash against the new cultural order. To illustrate this, it is useful to briefly discuss the recent demonstrations opposing the introduction of austerity measures in Greece and the background to the introduction of these measures.

\subsection{Greece}

The news reports and images of violent demonstrations and strikes in Greece in 2011 which shocked the world effectively had their commencement in 2008 with a series of demonstrations and strikes by young people as a response to high unemployment and changes to university education entrance requirements, the increasing high education costs and low post education salaries (Sotiris, 2010). In 2007, there was more than 20\% youth unemployment which was one of the highest in Europe. According to Sotiris (2010) this protest movement was triggered by a perception of social inequities and imbalance as well as a failure by public authorities to adequately respond to these concerns.

In 2010, in response to the global financial crisis and the associated world financial crisis, Greece, facing a national debt of $13 \%$ of GDP, was called upon by the International Monetary Fund and the EU to introduce drastic measures to reign in and reduce national debt. The austerity measuresproposed included massive reductions in wages of government employees, lower pensions and higher retirement age, increased value-added tax as well as increased taxes on alcohol and tobacco, and a significant reduction in military expenses (Renn, Jovanovic\&Schröter, 201; OECD, 2011). This proposed reduction resulted in not only a resumption of demonstrations by the young, but by massive demonstrations by government employees, pensioners, and labour unions, as well as other affected members of the Greek community. According to Renn et al (2011) in 2010 the focus of the organisation lay with the labour unions who claimed that the austerity measures were aimed at the socially disadvantaged and the already poor sections of the community, whilst protected the rich.

In relation to this last point itis important to put these demonstrations and protests into a broader context. Greek political culture has for many years been one of patronage and populism (Pappas, 2010). Over many years, fiscal discipline had all but been abandoned with sharp pay rises in the public sector, the introduction of universal free health care, significant rises in social welfare payments and other benefits, combined with massive tax evasion and a failure of the government tothe state implement effective tax policies. Attempts as far back as 1985 to introduce some austerity measures and freeze wages by the Papandreou government were met with calls by the unions for immediate pay rises or face electoral defeat. The populist response, despite the obvious need for financial austerity, was to essentially to throw open the financial coffers and declare that people were more important than the state institutions. The only government to attempt to introduce fiscally austere measures was that led by Constantine Mitsotakis who came to power in 1990. His government fell three years later and historically can lay claim to the only government in post-authoritarian Greece not be given a second chance in office. When one also considers the large-scale political patronage that has been a central part of Greek politics for decades, and the extensive corruption in the public sector - in 2009 an average of $€ 1,355$ per person was paid in bribes for such processes as speeding up obtaining a driver's licence, getting admitted to public hospitals, or manipulating tax returns (Pappas, 2011) - then the social cultural background to the recent demonstrations is firmly identified. The perception that thenew cultural order which is being forced upon the Greek people through the implementation of austerity measure is unjust fuels the backlash against the order and in turn creates the political unrest and violence which has been evident in Greece.

When one considers Greece's trading position, it is also evident that the globalization process has not been positive for Greece. According to the U.S. Department of State's Background Note on Greece (2011) foreign direct investment inflows to Greece have dropped and continue to be threatened due to declining competitiveness, 
and a high level of red tape and bureaucracy. Further, 79\% of Greek GDP is generated through a service economy, which includes tourism, and there is a perennial merchandise trade deficit with 2010 trade imports amounting to $\$ 64.5$ billion as compared to exports of $\$ 22$ billion. According to Gissinger and Gleditsch (1999) foreign direct investment and high levels of trade generally lead to higher levels of economic welfare but only where the trade balance is weighted towards exports rather than imports and there is an openness to the international market. Greece has also relied heavily on its EU trading partners with more than half of Greek trade being intra-EU, and on EU structural funding, and thus has not had the openness to the globalized international market which would seem critical for social equality. An inability to attract and keep foreign investment combined with a significant trade imbalance and insufficient engagement in the international trade market arguably leaves Greece vulnerable to on-going social unrest and instability, underpinned by high unemployment, social inequality, and government instability. The question now to be asked is whether the imposition of austerity measures and social unrest of themselves undermine sovereignty, and it is to that question that this paper will now turn.

\section{Sovereigntyand Social Unrest}

As previously discussed in this paper, sovereignty is the independence of the state to exercise within its territorial boundaries the functions of that state together with the obligation of the state to govern the economy in such a way as to promote the wealth and welfare of the community, ensuring liberty, security and prosperity, and ensuring that the specific social needs of the community are met. However, as this paper has also discussed, globalization has directed impacted upon sovereignty by challenging the competence of the state to exercise autonomous powers where the exercise of those autonomous powers directly impact upon the globalized framework within which that state operates.So what impact does social unrest have upon sovereignty, and does conditionality undermine sovereignty and drive social unrest?

The social unrest which has plagued Greece in recent months has been driven by the imposition of austerity measures demanded by Eurozone leaders concerned that Greek debt would undermine the stability and value of the euro. However, the imposition of austerity measures in response to debt crises is not a new phenomenon nor is the outbreak of social unrest in response to such imposition. The International Monetary Fund (IMF) has been imposing austerity type measures on countries under its Structural Adjustment Programs for decades, and there is widespread acknowledgment that there is a link between the imposition of these programs and social unrest in the form of public demonstrations, strikes and violent clashes with police. The purpose of these programs is to impose 'conditions' on the recipient country so as to increase economic viability, by liberalizing trade, expanding privatization and stabilizing the macroeconomic environment, whilst at the same time curbing government expenditure (Stroup \&Zissimos, 2011) Essentially, therefore, what is being imposed by these measures, whether by the IMF or the Eurozone in the case of Greece, is change, and the correlation with social unrest is that social unrest is also directed at bringing about change.

Gallano (1994), in his discussion on the Brazilian debt crisis of the 1980's which saw the IMF institute significant austerity and debt restructuring measures on Brazil, proposes that whilst the conditions imposed by the IMF on Brazil could be seen as violating or undermining Brazilian sovereignty by interfering with domestic politics and the right of the nation state to govern autonomously, the consent of Brazil to the austerity measures legitimized the inference and thus there was no violation of sovereignty, and therefore no violation of international law.

However, can consent to the imposition of rigorous austerity measures be regarded as being freely and validly given by a sovereign state where the consequences of not giving consent effectively economically isolates that state, with the consequences that flow from that isolation? In many of the debates around the Greek crisis and the bailout package deals, there were many calls for Greece to be effectively 'cut loose' from the European Union. In other words, Greece as a sovereign state, albeit part of the European Union, needed to be left to its own economic future, however dire the consequences of that may be. The decision to 'bailout' Greece and the consequential imposition of austerity measures gave rise to the widespread strikes, demonstrations and violence that were broadcast around the world. It is arguable that Greece consented to intervention when as a sovereign state it ratified the Treaty on European Union and the amending Treaty of Lisbon, (and it is noted, has subsequently agreed to the yet to be finalized Franko-German amendments to the Treaty of Lisbon which would impose automatic sanctions on Eurozone members who fail the new anti-deficit rules to be adopted by members), and entered membership of the Eurozone.

If sovereignty is the basic structure of governance which binds the state and its citizens together, with the objectives of peace, order, justice and security grounded in a managed national economy (Devetak\&Higgott, 
1999), then Greece has failed. A sovereign state which fails to provide the governance structure to meet these objectives, and in doing creates a disintegrating society which threatens the inter-dependent international community in which it exists, arguably loses the right to be sovereign, and thus loses the right to the benefits of economic and financial decision making which are ascribed to a sovereign state. Accordingly, given that a state operates in a globalized framework and we live, as was stated by the United National High Level Panel on Financing for Development in its 2001report, in a 'global village' the need forconsent to intervention andtheimposition of austerity measures loses its validity, as does the right to the claim sovereignty in economic and financial matters. There is no question that conditionality in the form of austerity measures drives social unrest. There is also no question that social unrest undermines sovereignty, as governments forced by the imposition of austerity measures face electoral backlash and failure, undermining the political framework of the state and raising the risk ratings of that state, which makes global economic and financial engagement more problematic. This in turn undermines any capacity to govern in the manner which would otherwise be expected by the global community.

\section{Social Unrest and International Law}

Globalization has challengedthe scope and role of the state and it is argued, has undermined state sovereignty to the extent that where democratic governance processes fail to generate a sustainable economic and fiscal environment which then directly impacts the external and transnational environment in which that state seeks to operate, then the state loses the sovereign right under international law to govern autonomously. Cerney (1999) refers to globalization as leading to a world which is characterized by a confusion of overlapping governance structures and processes which undermine and delegitimize democratic governance resulting in what he calls a 'multilayering of authority' which fragments identities, alienates individuals from the democratic political processes and erodes any notion of public interest.

This fragmentation and alienation it can be argued, is evidenced in the phenomenon of social unrest which, whilst this paper has discussed Greece, has also been seen in Italy, France, Spain, and even the United Kingdom following the global financial crisis and the need for the introduction of economic and fiscal austerity measures. This social unrest has taken various forms from riots, strikes and demonstrations, to the 'Occupy Wall Street' movement and it's offshoots around the world, and there is a grim warning from the International LabourOrganisation that the risk of social unrest is rising due to discontent over the lack of employment opportunities and the belief that the burden of the crisis is not being shared equally (International LabourOrganisation, 2011).

Of course, the social unrest which is currently evident in Syria, and that of Egypt, Yemen and Libya may not be obviously directly linked to globalization, but there is still an essence of globalization in this unrest, if only in the context of the tools of social media which have allowed images of the unrest to be broadcast around the world and the calls by the participants for intervention by the global community to secure peace, order, justice and security, which are the expected characteristics of sovereignty, as well as equality and prosperity. Globalization has created expectations which in turn have created a new social bond extending beyond state borders and essentially removing the monopolization by the state of authority, territory and community (Devetak\&Higgott, 1999). This new social bond has created a new world order where the benefits of globalization are seen and desired while the perceived detriments are amplified and rejected, with social unrest the tool being used to achieve these outcomes.The challenge for international law is to meet the challenges of this social unrest within the structure of a new social bond.

Väyrynen (2001) discusses the existence of a transnational society where transnational social spaces exist, separating social relations from local contexts and restructuring them in a global time-space framework. The existence of a transnational society with a separate network of power and interaction from that of the individual state provides a challenge as no one government or international organization is able to control effectively many of the aspects of that society. The tool of social media is an example of this power and interaction, and whilst countries such as China have sought to limit the scope of information being disseminated through social media, the effectiveness and power of social media has been and remains evident and real. It could even be argued that this transnational society is redefining globalization by having the ability to block or hinder progress in inter-state relationships as well as redefining the values, ethics and issues that drive the key players in the globalization movement.

International law is no stranger to mass action, and a considerable body of international law has had as its catalyst significant mass action events (Rajagopal, 2003). The response of international law has been to regulate, for with regulation comes the power to enforce. However, if the power to enforce becomes compromised 
because the 'enforcers' lack either the collective 'political' will or are themselves driven not by a need to regulate but by their globalization linkages, then international law as a regulatory tool, fails, as do the organizations established to enforce that law. Significant criticism has been leveled, for example, at the United Nations for its failure to act decisively in major conflicts around the world, given the responsibility of the United Nations for collective security (UN, 2004). The United Nations is chartered to “...maintain international peace and security...”by the use of collective action suppressing acts of aggression or breaches of the peace. However, the power of the permanent members of the United Nations Security Council to veto resolutions of intervention, effectively diminish the enforcement powers of United Nations, as has been seen recently in the case of Syria, where China and Russia exercised this right of veto (Note 2.)If international organizations such as the United Nations, chartered with the power to enforce international law, fail to act or fail to act quickly and decisively, then the transnational society - the new social bond - will use social unrest and social media to destabilize and force action to be taken. In essence, there is a metamorphosis of a new type of sovereignty, the sovereignty of the transnational society which legitimizes social unrest.

\section{Conclusion}

Globalization has changed the nature of national and international relationships by creating new and powerful transnational networks of power and interaction. Sovereignty as a concept has also been changed in this process, and the debate will doubtless continue as to the extent of this change. However, as this paper has discussed, embedded in the right to claim sovereign status is the obligation to provide peace, order, justice and security, and arguably a sound economic and fiscal basis to society. A sovereign state no longer operates purely autonomously, as globalization has effectively marginalized this ability, and requires the state to consider the broader transnational implications of its policies and actions, as a failure to meet these obligations has transnational or cross border implications.

The consequences of the global financial crisis on international relationships created and driven by globalization have, it would appear, to have been underestimated. The power of social unrest and the creation of a new 'global village', a transnational society with new tools, such as social media, and a collective 'sovereign' will, have redefined the world in which we live and in doing so, have challenged the scope and parameters of international law. Whether there is a collective political will strong enough to work towards a new understanding of international law in a globalized world is yet to be seen, for it will not be easy nor will it necessarily be welcomed by powerful interests which benefit and profit from the status quo, not by those who fear that they will become even more marginalized in the process. But these are not reasons for not moving towards a new understanding.

The social unrest movement has highlighted that only collectively will the basic goods for a just global village be provided and if this is so, then governance must be exercised at a global level, but this requirements tolerance, transparency, dialogue and commitment. International law and international legal institutions have a key role to play and whilst they may well be ill-equipped at this point to effectively address the demands and consequences of globalization and social unrest, they provide a starting point and at this time, a starting point is better than no point at all.

\section{References}

Blackhurst, R. (1997). The WTO and the Global Economy. The World Economy, 20(5), 527-540. http://dx.doi.org/10.1111/1467-9701.00087

Cerney, P.G. (1999). Globalization and the erosion of democracy. European Journal of Political Research, 36, 1-26. http://dx.doi.org/10.1111/1475-6765.00461

Devetak, R., \& Higgott, R. (1999). Justice Unbound? Globalisation, States and the Transformation of the Social Bond. International Affairs, 75(3), 483-498. http://dx.doi.org/10.1111/1468-2346.00089

Gallano III, A. (1994).International Monetary Fund Response to the Brazilian Debt Crisis: Whether the Effects of Conditionality Have Undermined Brazil’s National Sovereignty. Pace International Law Review, 6, 323-351

Gissinger, R., \& Gleditsch, N.P. (1999). Globalization and Conflict: Welfare, Distribution, and Political Unrest. Journal of World-Systems Research, 5(2), 327-365

Gunter, B.G., \& van der Hoeven, R. (2004). The social dimension of globalization: a review of the literature.Working Paper 24, Policy Integration Department, World Commission on the Social Dimension of Globalization, International Labour Office, Geneva. 
Howard-Hassmann, R.E. (2004). Culture, Human Rights, and the Politics of Resentment in the Era of Globalization. Human Rights Review, Oct-Dec, 5-26

Hurtado, M. de la Madrid (1997). National Sovereignty and Globalization.Houston Journal of International Law (Foreward), 553-563.

International Institute for Labour Studies (2011). World of Work Report 2011 - Making markets work for jobs. International LabourOrganisation: Geneva.

International Monetary Fund, World Economic Outlook (May 1987). Retrieved from http://www.imf.org/external/pubs/weomay/weocon.htm

Island of Palmas Hague Court Reports 2d 83 (1932). (Perm.Ct. 4rb 1928) 2 U.N. Rep. Intl. Arb. Awards 829.

Kwaka.E. (2000). Regulating the International Economy: What Role for the State? In M. Beyers, (2000) The Role of Law in International Politics (pp.227-246). New York: Oxford University Press.

OECD (2011). Reviews of Risk Management Policies - Future Global Shocks: Improving Risk Governance. Retrieved from http://www.oecd.org/dataoecd/24/36/48256382.pdf

Pappas, S. (2010). The Causes of the Greek crisis and in Greek Politics. Retrieved from http://www.opendemocracy.net/openeconomy/takis-s-pappas/causes-of-greek-crisis-are-in-greek-politics.ht $\mathrm{m}$

Rajagopal, B. (2003). International Law and Social Movements: Challenges of Theorizing Resistance'. Columbia Journal of Transnational Law, 41(2), 397-433.

Renn, O., Jovanovic, A., \& Schröter, R. (2011). Social Unrest.Multi-Disciplinary Issues International Future Programme, OECD paper IFP/WKP/FGS/ (2011). Retrieved from http://www.oecd.org/dataoecd/57/62/46890018.pdf

Seita, A.Y. (1997). Globalization and the Convergence of Values.Cornell International Law Journal,30, 429-492.

Singer, P. (2002). One World - the ethics of globalisation. New York:YaleUniversity Press

Sjolander, C.T. (1996). The Rhetoric of Globalization: What's in a Wor(l)d? International Journal, 51, 603. http://dx.doi.org/10.2307/40203150

Sotiris, P. (2010). Rebels with a Cause: The December 2008 Greek Youth Movement as the Condensation of Deeper Social and Political Contradictions. International Journal of Urban and Regional Research, 34(1) 203-209. http://dx.doi.org/10.1111/j.1468-2427.2010.00949.x

Stiglitz, J.E. (2002). Globalization and its discontents (London: Penguin)

Stiglitz, J.E. (2003). Globalization and growth in emerging markets and the New Economy.Journal of Policy Making, 25 505-524. http://dx.doi.org/10.1016/S0161-8938(03)00043-7

Stroup, C., \& Zissimos, B. (2011). Social Unrest in the Wake of IMF Structural Adjustment Programs. Retrieved from http://people.bath.ac.uk/bbcz20/papers/StroupZissimos11b.ppdf

United Nations (2000). Millenium Report of the Secretary General. Retrieved from http://www.un.org/millenium/sg/report

United Nations (2001). Report of the High-Level Panel of Financing for Development appointed by the United Nations Secretary-General, United Nations General Assembly. A./55/1000. Retrieved from http://www.un.org/reports/financing/full_report.pdf

United Nations (2004). A more secure world: our Shared Responsibility - Report of the High Level Panel on Threats Challenges and Change. Retrieved from http://www.in.org/secureworld/report3.pdf

United Nations (2011). Weighing Pro, Cons of Globalization, Second Committee Delegates Caution -Growth in Global trade, Interdependence Could Exacerbate Inequalities. Retrieved from http://www.un.org/News/Press/docs/2011/gaef3314.doc.htm

United States Department of State, Bureau of European and Eurasian Affairs Background Note: Greece 9 December, 201. Retrieved from http://www.state/gov/r/pa/ei/bga/3395.htm

Väyrynen, R. (2001). Sovereignty, globalization and transnational social movements.International relations of the Asia-Pacific, 1, 227-246. http://dx.doi.org/10.1093/irap/1.2.227

Westaway, J., \& Simpson, J. (2011). Disintegration of the Concept of Sovereignty and the Implications for the Energy Sector in Europe.In A. Dorsman, W. Westerman. O. Arslan, (Eds) Financial Aspects in Energy: A 
European Perspective. Heidelberg, Germany: Springer.

Yates, N. (1999) Social Politics and Policy in an Era of Globalization: Critical Reflections.Social Policy \& Administration, 33 (4), 372-393. http://dx.doi.org/10.1111/1467-9515.00159

\section{Notes}

Note 1 . It is to be noted that this paper does not attempt to discuss or provide any comparative analysis of the impact of globalization on the economic performance of counties, as this is beyond the scope and intent of this paper. An additional paper is in preparation by this author which will address globalization and economic performance.

Note 2. Russia has strong naval ties to Syria having facilities at both Latakia and Tartus. Syria is also Russia's most important trading partner in the region, with Russia being Syria's main arms supplier. China's opposition is arguably based on the belief that the conflict in Syria should be resolved by the Syrian people without international intervention. See the United Nations Press release on the veto at http://www.un.org/News/Press/docs/2012/sc10536.doc.htm 